\title{
JEKK
}

Jurnal Epidemiologi Kesehatan Komunitas

$2(2), 2017,99-108$

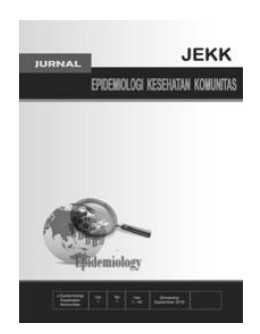

\section{Faktor Karakteristik Klinis Host dan Sosiodemografik yang Berpengaruh Terhadap Kejadian Dengue Shock Syndrome}

\author{
Dias Irawan Prasetya ${ }^{*}$, Suharyo Hadisaputro ${ }^{* *}$, Muchlis Achsan Udji Sofro ${ }^{* * *}$, Djoko Trihadi \\ Lukmono $^{* * * *}$, Martini $^{* * * * *}$ \\ "Dinas Kesehatan Kota Semarang, ${ }^{* *}$ Politeknik Kesehatan Semarang, ${ }^{* * *}$ Fakultas Kedokteran Undip, \\ ${ }^{* * * * * *}$ RSI Sultan Agung Semarang, ${ }^{* * * * * *}$ Fakultas Kesehatan Masyarakat Semarang
}

\begin{abstract}
Background : Dengue Shock Syndrome (DSS) is DHF grades III and IV, which can result in disease severity and lead to the death. In 2016, the number of DHF/DSS cases in Semarang City was 2.200 cases ( $I R=124,50)$ with 293 cases DSS or $15,4 \%$ from DHF, and CFR DSS cases is $9,21 \%$.

Methods : An observational analytic was conducted with case-control study design. Study populations were patients with diagnosis of DSS or diagnosis of DHF that admitted in K.R.M.T Wongsonegoro Hospital Semarang City. The samples were 70 cases and 70 controls by consecutive sampling. Data were analyzed by logistic regression.

Results : Patients DHF with age $\leq 15$ years $\mathrm{OR}=4,277(95 \% \mathrm{CI}=1,325-13,598)$, secondary infection $\mathrm{OR}=2,807$ (95\% $\mathrm{CI}=1,116-7,055)$, hepatomegaly $\mathrm{OR}=3,206(95 \% \mathrm{CI}=1,055-$ $9,745)$ and thrombocytopenia $(<50.000 / \mu \mathrm{L})$ OR=11,301 $(95 \% \mathrm{CI}=4,674-27,325)$ is a factors that influenced for incidence of dengue shock syndrome. Sex, nausea/vomiting, hemoconcentration, BMI, blood type, prolonged acces to health services, signs of spontaneous bleeding, abdominal pain, hypotension, acces to health services, knowledge and awareness of parents / suffers were not associated with DSS.

Conclusion : Host clinical characteristic variables were evident influenced to DSS is age $\leq 15$ years, secondary infection, hepatomegaly, and thrombocytopenia $(<50.000 / \mu \mathrm{L})$.
\end{abstract}

Keywords: Dengue shock syndrome; dengue haemorrhagic; host clinical characteristic

Penulis korespondensi : dirasetyairawan@gmail.com 


\section{Pendahuluan}

Dengue Shock Syndrome (DSS) merupakan fase ketiga dan keempat dari perkembangan penyakit Demam Berdarah Dengue, dimana sudah terjadi syok pada penderita demam berdarah. ${ }^{1}$ Demam Berdarah Dengue adalah salah satu penyakit yang disebabkan oleh infeksi salah satu atau beberapa serotipe dari 4 jenis virus dengue, yaitu: Den-1, Den-2, Den-3, dan Den-4 yang ditularkan melalui gigitan nyamuk Aedes sp. yaitu Aedes aegypti atau Aedes albopictus yang sudah terdapat virus di dalam tubuhnya. 1,2

Demam berdarah merupakan suatu penyakit tular nyamuk terbesar kasusnya di dunia. Dalam 50 tahun terakhir, angka kejadian selalu mengalami peningkatan, diperkirakan terdapat 50 juta kasus demam berdarah terjadi di dunia setiap tahunnya dan kira-kira terdapat 2,5 milyar penduduk yang tinggal pada negara endemis demam berdarah. $^{3}$ Berdasarkan hasil penelitian melaporkan bahwa 70\% dari infeksi DENV terjadi di Asia. ${ }^{4}$

Angka kejadian kasus DBD di Indonesia pada tahun 2015 sebesar 129.650 kasus (IR=50,75), dengan jumlah kasus meninggal sebanyak 1.071 kasus $(\mathrm{CFR}=$ $0,83 \%$ ) dan di Provinsi Jawa Tengah pada tahun 2015, angka kesakitan/ Incidence Rate (IR) DBD sebesar 47,9 per 100.000 penduduk. ${ }^{5}$ Di Kota Semarang, sejak tahun 2008-2014 menempati peringkat pertama (tahun 2013 menempati peringkat kedua) berdasarkan angka kejadian DBD di Provinsi Jawa Tengah, dimana $>80 \%$ kelurahan merupakan endemis DBD. ${ }^{6}$

Pada tahun 2015 jumlah kejadian DBD di Kota Semarang sebanyak 1.737 kasus (IR=98,61) dengan angka kematian sebanyak 21 kasus $(\mathrm{CFR}=1,2 \%)$, dan pada tahun 2016, jumlah kasus DBD dan DSS di Kota Semarang sebanyak 2.200 kasus $(\mathrm{IR}=124,50)$. Jumlah kasus DBD sebanyak
1.907 kasus dan jumlah kasus DSS sebanyak 293 kasus atau 15,4\% dari kasus DBD. Berdasarkan jumlah kasus DSS tahun 2016 tersebut, angka kematian DSS di Kota Semarang yang dilaporkan mencapai 27 kasus (CFR DSS=9,21\%) dan jumlah kematian DSS yang terbanyak dilaporkan adalah sebanyak 7 kasus kematian dari 85 kasus DSS yang dirawat di RSUD K.R.M.T. Wongsonegoro Kota Semarang. ${ }^{7}$

Faktor risiko DSS yaitu umur, jenis kelamin, status gizi, lama mendapatkan layanan kesehatan, infeksi dengue ulangan, dan jenis serotipe virus. ${ }^{8-11}$ Penelitian Rahayu dan Kalayanaroj, et al, juga menyebutkan bahwa golongan darah $\mathrm{AB}$ merupakan faktor risiko dari kejadian DSS. $^{12,13}$ Secara klinis, faktor yang berhubungan dengan DSS yaitu mual, muntah, hipotensi, nyeri abdominal, perdarahan pada sistem gastrointestinal, hemokonsentrasi, efusi pleura, hipoalbuminemia, hipoproteinemia, hepato-megali, tromposito-penia, tingkat fibrinogen, protrombin dan tromboplastin time, serta tingkat alanine transaminase. ${ }^{8,10,14-18}$ Namun dalam faktor-faktor yang berhubungan masih terdapat hasil yang saling bertolak belakang antara beberapa hasil penelitian, misalnya variabel umur, jenis kelamin perempuan, dan golongan darah.

Selain faktor klinis yang terbukti sebagai faktor risiko DSS, juga terdapat faktor lingkungan dan sosio demografik yang besar kemungkinan juga menjadi faktor risiko DSS yaitu akses terhadap pelayanan kesehatan, pengetahuan dan kesadaran orangtua penderita mengenai DBD. ${ }^{19-22}$ Persepsi individu yang kurang baik dalam memahami penyakit DBD yang dianggap seperti demam pada umumnya, sehingga akhirnya ada keterlambatan dibawa ke fasilitas kesehatan dan dirujuk ke rumah sakit, dan menyebabkan tingkat keparahan penyakit DBD meningkat dan terjadi syok. $^{23}$ 
Berdasarkan penjelasan dan uraian tersebut, peneliti tertarik untuk meneliti lebih lanjut mengenai faktor karakteristik klinis host dan sosio demografik yang berpengaruh dengan kejadian DSS di Kota Semarang dengan melakukan studi di RSUD K.R.M.T Wongsonegoro Kota Semarang, karena selama ini belum pernah dilakukan penelitian.

\section{Metode}

Penelitian ini dilaksanakan dengan melakukan pencatatan data rekam medis pasien DSS dan pasien DBD di RSUD K.R.M.T Wongsonegoro Kota Semarang dan kunjungan rumah untuk mengetahui pengetahuan dan kesadaran orangtua/ penderita serta pengukuran jarak rumah terhadap fasilitas pelayanan kesehatan.

Penelitian ini menggunakan desain studi case control. Populasi studi kasus adalah penderita DBD yang berkembang menjadi DSS dan dirawat di RSUD K.R.M.T Wongsonegoro Kota Semarang. Populasi studi kontrol adalah penderita DBD yang tidak berkembang menjadi DSS dan di rawat di RSUD K.R.M.T Wongsonegoro Kota Semarang. Penentuan kriteria DBD dan DSS menggunakan kriteria WHO tahun 1997.

Teknik pengambilan sampel menggunakan teknik pemilihan tidak berdasarkan peluang (non-probability sampling). Teknik pengambilan sampel kasus dan kontrol dilakukan dengan consecutive sampling yaitu berdasarkan urutan data sekunder dari register kasus DBD/ DSS di RSUD K.R.M.T. Wongsonegoro Kota Semarang yang memenuhi kriteria inklusi dan eksklusi. Jumlah responden dalam penelitian ini didapatkan berdasarkan perhitungan dengan rumus Lameshow, dimana proporsi pengaruh terhadap kelompok kontrol (P2) adalah 0,68 dan terhadap kelompok kasus (P1) adalah 0,88, dengan $\alpha$ adalah 0,05 (Z $\alpha$
$=1,96)$ dan $\beta$ adalah $0,2 \quad(Z \beta=0,842)$ sehingga didapatkan jumlah responden dalam setiap kelompok 66 orang, dan dalam penelitian ini dibulatkan 70 orang, dengan perbandingan kelompok kasus dan kontrol $1: 1$, sehingga jumlah total responden ada 140 responden (70 kasus dan 70 kontrol).

Data didapatkan dari catatan rekam medis,KDRS, dan kuesioner. Tidak terdapat variabel confounding dalam penelitian ini. Variabel yang diteliti adalah umur $(\leq 15$ tahun), jenis kelamin, IMT, golongan darah ( $\mathrm{AB}$ dan non $\mathrm{AB}$ ), lama mendapatkan pelayanan kesehatan ( $>4$ hari), infeksi ulangan (IgG positif), tanda perdarahan spontan, mual/muntah, nyeri abdominal, hipotensi (sistolik $\leq 80 \mathrm{~m} \mathrm{mHg}$ ), hemokonsentrasi ( $\geq 22 \%$ ), hepatomegali, trombositopenia $(<50.000 / \mathrm{L})$, akses menuju fasilitas kesehatan $(>5 \mathrm{~km})$, serta pengetahuan dan kesadaran orangtua/penderita terhadap penyakit demam berdarah dengue. Data dianalisis secara bivariat dengan uji statistik chi square dan analisis multivariat dengan uji regresi logistik. Hasil odds ratio dengan tingkat kepercayaan $95 \%$ digunakan untuk mengetahui faktor yang berpengaruh terhadap kejadian DSS.

\section{Hasil}

Berdasarkan karakteristik responden, sebagian besar penderita DBD dan DSS memiliki umur $\leq 15$ tahun $(79,3 \%)$, jenis kelamin yang hampir setara; laki-laki $(47,1 \%)$ dan perempuan $(52,9 \%)$, memiliki IMT yang normal $(63,6 \%)$, golongan darah non $\mathrm{AB}(80,0 \%)$, lama mendapatkan pelayanan kesehatan $>4$ hari $(59,3 \%)$, terdapat infeksi ulangan $(65,7 \%)$, tidak terdapat tanda perdarahan spontan $(63,6 \%)$, mengalami mual/muntah $(73,6 \%)$, mengalami nyeri abdominal $(65,0 \%)$, tidak terjadi hipotensi $(85,0 \%)$, tidak terjadi hemokonsentrasi $\geq 22 \%(70,0 \%)$, tidak terjadi hepatomegali $(75,7 \%)$, tidak terjadi trombositopenia $(52,9 \%)$. Berdasarkan sosio 
demografik, semua penderita DBD dan penderita DSS memiliki kemudahan akses terhadap fasilitas pelayanan kesehatan $(100,0 \%)$, dan memiliki tingkat pengetahuan dan kesadaran terhadap demam berdarah dengue rendah (59,3\%).

Hasil analisis bivariat dengan menggunakan uji chi square diketahui faktor yang berpengaruh terhadap kejadian DSS adalah umur $\leq 15$ tahun $(\mathrm{p}=0,002 ; \mathrm{OR}=$ 4,$125 ; 95 \% \mathrm{CI}=1,628-10,452$, jenis kelamin perempuan $(\mathrm{p}=0,007 ; \mathrm{OR}=2,545 ; 95 \% \mathrm{CI}$ $=1,287-5,033)$, infeksi ulangan $(\mathrm{p}=0,013$; $\mathrm{OR}=2,478 ; 95 \% \mathrm{C}=\mathrm{I} 1,204-5,100), \quad \mathrm{mual} /$ $\operatorname{muntah}(\mathrm{p}=0,013 ; \mathrm{OR}=2,685 ; 95 \% \mathrm{CI}=1,218$ 5,291), hemokonsentrasi ( $\geq 22 \%)(\mathrm{p}=0,001$; $\mathrm{OR}=3,625 ; 95 \% \mathrm{CI}=1,660-7,918)$, hepatomegali $(\mathrm{p}=<0,001 ; \mathrm{OR}=5,651 ; 95 \% \mathrm{CI}=2,258$ $-14,142)$ dan trombositopenia $(<50.000 / \mu \mathrm{L})$ $(\mathrm{p}=<0,001 ; \mathrm{OR}=13,670 ; 95 \%$ CI $6,061-$ 30,828) (Tabel 1).

Tabel 1. Analisis bivariat terhadap kejadian DSS

\begin{tabular}{|c|c|c|c|c|c|}
\hline \multirow{2}{*}{ No } & \multirow{2}{*}{ Variabel } & \multirow{2}{*}{ Nilai $\mathrm{p}$} & \multirow{2}{*}{ OR } & \multicolumn{2}{|c|}{$95 \% \mathrm{CI}$} \\
\hline & & & & Bawah & Atas \\
\hline 1. & Umur & 0,002 & 4,125 & 1,628 & 10,452 \\
\hline 2. & Jenis Kelamin & 0,007 & 2,545 & 1,287 & 5,033 \\
\hline 3. & Indeks Masa Tubuh (IMT) & 0,598 & 1,203 & 0,604 & 2,398 \\
\hline 4. & Golongan Darah & 0,205 & 1,720 & 0,740 & 4,002 \\
\hline 5. & Lama Mendapatkan Pelayanan Kesehatan & 0,606 & 0,837 & 0,426 & 1,644 \\
\hline 6. & Infeksi Ulangan & 0,013 & 2,478 & 1,204 & 5,100 \\
\hline 7. & Tanda Perdarahan Spontan & 0,598 & 1,203 & 0,604 & 2,398 \\
\hline 8. & Mual/muntah & 0,013 & 2,685 & 1,218 & 5,921 \\
\hline 9. & Nyeri Abdominal & 0,111 & 1,768 & 0,875 & 3,574 \\
\hline 10. & Hipotensi (<80 mmHg) & 0,478 & 0,713 & 0,280 & 1,818 \\
\hline 11. & Hemokonsentrasi $(\geq 22 \%)$ & 0,001 & 3,625 & 1,660 & 7,918 \\
\hline 12. & Hepatomegali & $<0,001$ & 5,651 & 2,258 & 14,142 \\
\hline 13. & Trombositopenia $(<50.000 / \mu \mathrm{L})$ & $<0,001$ & 13,670 & 6,061 & 30,828 \\
\hline 14. & Akses Menuju Fasilitas Kesehatan & - & 1,000 & - & - \\
\hline 15. & Pengetahuan dan Kesadaran Orangtua/Penderita & 0,390 & 1,345 & 0,684 & 2,646 \\
\hline
\end{tabular}

Tabel 2. Hasil uji multiple logistic regression faktor karakteristik host dan sosio demografik yang berpengaruh terhadap kejadian DSS

\begin{tabular}{clrrrr}
\hline No & \multicolumn{1}{c}{ Variabel } & B & Nilai $\mathrm{p}$ & Exp (B) / OR & \multicolumn{1}{c}{ 95 \% CI } \\
\hline 1. & Infeksi ulangan & 1,032 & 0,028 & 2,807 & $1,116-7,055$ \\
2. & Hepatomegali & 1,165 & 0,040 & 3,206 & $1,055-9,745$ \\
3. & Umur & 1,453 & 0,014 & 4,277 & $1,345-13,598$ \\
4. & Trombositopenia & 2,425 & $<0,001$ & 11,301 & $4,674-27,325$ \\
\hline & Constant & $-3,221$ & 0,000 & 0,040 & \\
\hline
\end{tabular}

\section{Pembahasan}

Analisis multivariat menunjukkan hasil bahwa penderita DBD yang mempunyai rentang umur $\leq 15$ tahun mempunyai risiko 4,277 kali lebih besar mengalami kejadian dengue shock syndrome dibandingkan penderita yang mempunyai rentang umur di atas itu. $(\mathrm{p}=0,014 ; 95 \% \mathrm{CI}$ $=1,345-13,598)$. Umur anak-anak rentan terhadap penyakit karena daya tahan tubuh yang belum stabil. $^{24}$ Umur merupakan variabel yang penting dari seseorang karena angka kesakitan dan kematian 
hampir semua keadaannya menunjukkan hubungan dengan usia. ${ }^{25}$ Apabila menyangkut dengan keparahan penyakit dengue, salah satu faktor risiko secara epidemiologi adalah umur ketika terkena infeksi, ini bisa terjadi karena terdapat perbedaan tingkat demam berdarah secara klinis berdasarkan umur penderita. ${ }^{26}$ Pada usia bayi dan anak-anak pra-sekolah lebih sering didapatkan kasus demam, dibandingkan dengan anak pada usia pra-remaja, dan pada anak-anak yang lebih muda, banyak menderita demam berdarah dengue yang berkembang menjadi lebih parah. Hasil klinis (misalnya rasio kematian) lebih tinggi dibandingkan dengan kasus orang dewasa. ${ }^{26,27}$

Demam berdarah dengue adalah penyakit menular yang terutama menyerang anak-anak, beberapa laporan dari penelitian menunjukkan bahwa, anak dengan usia 5-9 tahun $(\mathrm{OR}=1,67,95 \% \mathrm{CI}=$ 1,08;2,58) lebih berisiko terhadap kejadian DSS dibandingkan kelompok umur yang lainnya. Hal ini dikarenakan kemungkinan terdapat tingkat mikrovaskuler dan permeabilitas yang tinggi pada umur dibawah 5 tahun dan diatas 9 tahun, dengan meningkatnya permeabilitas vaskuler dapat mengurangi risiko adanya kebocoran plasma. ${ }^{11}$ Pada penelitian Anders, et al ${ }^{11}$ menggambarkan bahwa anak yang berusia 6-10 tahun berisiko lebih tinggi mengalami DSS walaupun angka kematian lebih tinggi terjadi pada anak yang lebih muda usianya dan terjadi penurunan angka kematian seiring bertambahnya usia. ${ }^{11}$ Penelitian yang dilakukan Guzman et $a l^{26}$ didapatkan bahwa penduduk dengan umur sekitar 15 tahun, berisiko lebih tinggi terhadap kematian akibat demam dengue daripada penduduk dengan umur lebih tua. ${ }^{26}$ Penelitian yang dilakukan oleh Fulara ${ }^{28}$ di India, juga menyatakan bahwa bayi dan anak-anak dengan infeksi dengue sangat rawan untuk berkembang menjadi syok. ${ }^{28}$
Penderita DBD yang mempunyai riwayat infeksi virus dengue sebelumnya di dalam tubuhnya mempunyai risiko 2,807 kali lebih besar mengalami kejadian dengue shock syndrome dibandingkan penderita yang tidak mempunyai infeksi virus dengue sebelumnya. ( $\mathrm{p}=0,028 ; 95 \%$ CI 1,116-7,055). Selain faktor usia, faktor paritas infeksi juga merupakan salah satu faktor penting dalam hubungannya dengan keparahan penyakit dengue. ${ }^{27}$ Seseorang yang terkena infeksi virus dengue yang pertama akan menderita demam dengue dan individu tersebut akan memiliki kekebalan seumur hidup terhadap serotipe virus yang sudah pernah menyerangnya, namun terhadap serotipe virus dengue yang lain masih belum memiliki kekebalan. 3,29

Adanya reaktif silang yang terjadi akibat infeksi dengue sebelumnya, dapat meningkatkan infektifitas virus dengue yang dapat menyebabkan persebaran penyakit yang lebih berat dan parah. Berbagai macam infeksi ulangan berkaitan dengan terjadinya wabah DBD/DSS dimana kasusnya berat dan terjadi pada anak-anak. $^{27}$

Penderita infeksi dengue yang disebabkan oleh infeksi ulangan mempunyai kadar trombosit yang lebih rendah serta nilai ALT yang lebih tinggi sehingga berdampak dengan keparahan penyakit. ${ }^{30}$ Penelitian oleh Khurram et $a l^{30}$, mengungkapkan bahwa sebanyak $18,8 \%$ pasien demam dengue dengan infeksi primer dapat berkembang ke tahap dengue parah (DSS), sedangkan pada pasien dengue dengan infeksi ulangan, angkanya bisa mencapai $42 \%$ dari total pasien. ${ }^{30}$ Dalam penelitian ini menunjukkan bahwa infeksi ulangan berisiko hampir 3 kali lipat untuk pasien DBD bisa berkembang menjadi dengue shock syndrome, senada dengan penelitian dari Tantracheewathorn ${ }^{8}$ yang menunjukkan bahwa infeksi ulangan dapat menjadi faktor risiko terjadinya DSS sebesar 21,8 kali dibandingkan dengan 
infeksi primer atau infeksi yang pertama $\left(\mathrm{OR}=21,8\right.$ 95\%CI;5,3-90,8). ${ }^{8}$ Hal ini juga didukung dengan hasil penelitian Tee, et $a l^{17}$ yang membuktikan bahwa infeksi ulangan berisiko 2,27 kali berkembang menjadi DSS dibandingkan infeksi primer $\left(\mathrm{OR}=2,27\right.$ 95\%CI; 1,08-4,78). ${ }^{17}$

Penderita DBD yang mempunyai gejala hepatomegali mempunyai risiko 3,206 kali lebih besar mengalami kejadian dengue shock syndrome dibandingkan penderita yang tidak mempunyai gejala hepatomegali. $\quad(p=0,040 ; 95 \% \mathrm{CI}=1,055$ 9,745). Infeksi dengue, dimana terjadi kondisi viremia yang tinggi berdampak terhadap berbagai organ, misalnya hati dan otak, yang dapat berkembang ke dalam kondisi yang lebih parah. Hati merupakan organ yang paling umum terdampak pada infeksi dengue. Manifestasi hepatik merupakan hasil langsung dari adanya toksisitas virus dan respon imun tubuh terhadap virus. ${ }^{31}$ Pembesaran hati pada umumnya dapat ditemukan pada permulaan penyakit DBD, bervariasi dari hanya sekedar dapat diraba (just palpable) sampai 2-4 $\mathrm{cm}$ di bawah lengkungan iga kanan dan dibawah Procesus xifoideus. Namun derajat besarnya pembesaran hati tidak selamanya tegak lurus dengan tingkat keparahan penyakit. $^{19}$ Meskipun gejala pembesaran hati lebih sering ditemukan pada penderita DBD dibandingkan penderita DD. Pada penelitian Ahmed ${ }^{32}$ yang dilakukan pada pasien DBD, pembesaran hati atau hepatomegali ditemukan pada $90 \%$ penderita anak-anak, dan $60 \%$ penderita dewasa. ${ }^{32}$

Infeksi virus dengue merupakan salah satu penyakit menular yang banyak menyerang anak-anak dan sangat ber-dampak pada gangguan hati terutama di negara-negara tropis. ${ }^{33}$ Penelitian Jagadish-kumar ${ }^{34}$ ) menyatakan keadaan hepato-megali merupakan tanda yang paling banyak ditemukan pada penderita infeksi dengue. Sebanyak 110 kasus infeksi dengue di dalam penelitian, didapatkan angka hepatomegali $79 \%$ dengan proporsi kejadian, $88,5 \%$ pada penderita DBD dan 96\% pada penderita DSS. Hubungan yang serupa antara hepatomegali dengan infeksi dengue juga banyak dilaporkan berkisar antara $43 \%-100 \%$ kasus pada anak-anak. ${ }^{34}$

Berdasarkan sebuah studi meta analisis terhadap gejala dan tanda DSS, didapatkan bahwa pasien dengan hepatomegali setelah terkena infeksi DBD diperkirakan memiliki a 5-fold yang mampu meningkatkan risiko keparahan penyakit menuju DSS, ${ }^{35}$ disfungsi hati pada infeksi dengue diakibatkan oleh adanya infeksi virus dengue pada sel hepatosit dan sel Kupffer yang merupakan target utama dalam proses infeksi. ${ }^{31}$

Bukti secara klinis, keadaan hepatomegali dan adanya peningkatan serum enzim dalam hati, menyebabkan infeksi virus dapat berkembang menjadi lebih parah. ${ }^{36}$ Dalam penelitian ini didapatkan bahwa keadaan hepatomegali berisiko berkembang menjadi DSS sebesar 3,2 kali, dan hal ini sesuai dengan penelitian Pongpan, et $a l^{37}$ yang menyatakan adanya tanda pembesaran hati atau hepatomegali, merupakan faktor risiko terhadap kejadian DSS dengan besar risiko 43 kali dibandingkan yang tidak mengalami hepatomegali $(\mathrm{OR}=43,44), 27$ kali pada penelitian di RS Hasan Sadikin Bandung $(\mathrm{OR}=27,72)$ dan 6,6 kali pada penelitian di RS Sanglah Denpasar Bali. ${ }^{37-39}$

Penderita DBD yang mempunyai keada-an trombositopenia $(<50.000 / \mu \mathrm{L})$ mem-punyai risiko 11,301 kali lebih besar mengalami kejadian DSS dibandingkan penderita yang mempunyai keadaan trombositopenia di atas itu. $(\mathrm{p}=<0,001 ; 95 \% \mathrm{CI}$ 4,674-27,325). Keadaan trombositopenia, merupakan keadaan yang paling sering ditemukan pada penderita infeksi virus dengue, ${ }^{40}$ dan menjadi salah satu kriteria dalam penegakkan diagnosa demam $d e$ ngue, bersama dengan kadar peningkatan 
hematokrit, dan tanda kebocoran plasma lainnya. ${ }^{3,19}$ Keadaan trombositopenia yang rendah mungkin berhubungan dengan perubahan pada megakaryocytopoieses oleh infeksi pada sel haematopoietic di manusia dan lemahnya regenerasi sel pertumbuhan, mengakibatkan disfungsi atau gangguan pada platelet (aktivasi dan penyatuan platelet), meningkatkan proses penghancuran atau konsumsi (penyerapan dan konsumsi perifer). ${ }^{40}$ Perdarahan mungkin terjadi akibat trombositopenia dan berhubungan dengan gangguan platelet atau penyebarluasan koagulasi intravascular. ${ }^{3}$

Terdapat hubungan antara keadaan trombositopenia dengan tingkat keparahan penyakit demam berdarah. Kadar trombosit $<50.000 / \mu \mathrm{L}$ berhubungan dengan kejadian perdarahan yang hebat. Perdarahan mungkin berhubungan dengan gangguan platelet, vaskulopati, dan atau koaguloapati yang berhubungan dengan perdarahan hebat yang berakibat pada kematian. ${ }^{37}$ Kombinasi dari kadar hemokonsentrasi yang tinggi, keadaan trombositopenia, dan tingkat AST yang tinggi merupakan faktor risiko terjadinya keparahan infeksi dengue pada orang dewasa. ${ }^{41}$

Pada penelitian meta analisis disebutkan bahwa terdapat hubungan dan merupakan faktor risiko antara kondisi trombositopenia dengan keparahan penyakit demam berdarah dengue (DBD) dan keadaan trombositopenia merupakan penanda keparahan penyakit dengue. ${ }^{10}$ Dalam penelitian ini didapatkan bahwa keadaan trombositopenia $(<50.000 / \mu \mathrm{L})$ berisiko 11,3 kali lipat untuk berkembang menjadi DSS. Hal ini sesuai dengan pernyataan penelitian oleh Mayetti ${ }^{42}$ juga menyatakan bahwa kadar trombosit $<50.000 / \mu \mathrm{L}$ merupakan faktor risiko terhadap kejadian DSS dimana pasien dengan kadar trombosit $<50.000 / \mu \mathrm{L}, 70 \%$ berkembang menjadi DSS dibandingkan dengan pasien dengan kadar trombosit diatas itu, ${ }^{42}$ dan penelitian oleh Pongpan et $a l^{43}$ yang juga menyatakan keadaan trombositopenia $(<50.000 / \mu \mathrm{L})$ berisiko hampir 4 kali lipat untuk berkembang menjadi dengue shock syndrome. ${ }^{43}$ Hasil penelitian ini, didapatkan rata-rata nilai trombosit pada kelompok kasus (DSS) adalah 38.500/ $\mu \mathrm{L}$, sedangkan pada kelompok kontrol (DBD) adalah $77.000 / \mu \mathrm{L}$.

\section{Kesimpulan}

Berdasarkan hasil penelitian maka dapat disimpulkan bahwa terdapat 4 variabel yang terbukti berpengaruh ter-hadap kejadian DSS, yaitu umur $\leq 15$ tahun, infeksi ulangan, hepatomegali dan trombositopenia $<50.000 / \mu \mathrm{L}$. Perhitungan menunjukkan bahwa 4 variabel yang berpengaruh dapat menyebabkan kejadian DSS pada pasien DBD dengan tingkat probabilitas atau risiko sebesar $94,51 \%$.

\section{Ucapan Terimakasih}

Terima kasih kepada staf RSUD K.R.M.T. Wongsonegoro Kota Semarang dan seluruh pihak yang telah mambantu peroses penelitian.

\section{Daftar Pustaka}

1. WHO. 1997. Dengue Haemorrhagic Fever: Diagnosis, Treatment, Prevention, and Control Geneva Switzerlands : WHO.

2. WHO. 2012. Handbook for Clinical Management of Dengue. Geneva, Switzerland: WHO Press.

3. WHO. 2009. Dengue : Guidelines For Diagnosis, Treatment, Prevention And Control. France : World Health Organization.

4. Bhatt S, Gething PW, Brady OJ, Messina JP, Farlow AW, Moyes CL, et al. 2013. The Global Distribution and Burden od Dengue. Nature.pp.504507. 
5. Sutardjo US, Primadi O, Sitohang V, Budijanto D, Hardhana B, Soenardi T, et al. 2016. Profil Kesehatan Indonesia Tahun 2015. Jakarta: Kementerian Kesehatan Republik Indonesia.

6. Endang, Pandu H, Prayitno G. 2015. Profil Kesehatan Kota Semarang 2014. Semarang: Dinas Kesehatan Kota Semarang.

7. Dinas Kesehatan Kota Semarang. 2016. Laporan Data Kasus DBD Tahun 2016. Semarang: Bidang P2P, Seksi P2B2.

8. Tantracheewathorn S. 2007. Risk Factors of Dengue Shock Syndrome in Children. J Med Assoc Thai.pp.90.

9. Widiyati MMT, Laksanawati IS, Prawirohartono EP. 2013. Obesity as a risk factors for Dengue Shock Syndrome in Children. Paediatrica Indonesiana.pp.53.

10. Huy NT, Van Giang T, Thuy DH, Kikuchi M, Hien TT, Zamora J, et al. 2013. Factors associated with dengue shock syndrome: a systematic review and meta-analysis. PLoS neglected tropical diseases.pp.7

11. Anders KL, Nguyet NM, Chau NVV, Hung NT, Thuy TT, Lien LB, et al. 2011. Epidemiological Factors Associated with Dengue Shock Syndrome and Mortality in Hospitalized Dengue Patients in Ho Chi Minh City, Vietnam. AmJ Trop Med Hyg.pp.127-134.

12. Rahayu, Hilmanto D, Setyabudi D. 2008. Golongan Darah AB sebagai Faktor Risiko Syndrom Shock Dengue pada Anak. Majalah Kedokteran Indonesia.pp.58.

13. Kalayanarooj S, Gibbons RV, Vaughn D, Green S, Nisalak A, Jarman RG, et al. 2007. Blood group AB is Associated with Increased Risk for Severe Dengue Disease in Secondary Infections. The Journal Of Infectious Diseases.195.pp.1014-1017.
14. Lam PK, Tam DT, Diet TV, Tam CT, Tien NT, Kieu NT, et al. 2013. Clinical characteristics of Dengue shock syndrome in Vietnamese children: a 10-year prospective study in a single hospital. Clinical infectious diseases : an official publication of the Infectious Diseases Society of America.57.pp. 1577-1586.

15. Piyakulmala T. 2008. Risk Factors of Dengue Shock Syndrome in Kalasin Hospital. Journal of Health Science. pp.17.

16. Junia J, Garna H, Setiabudi D. 2007. Clinical Risk Factors for Dengue Shock Syndrome in Children. Paediatrica Indonesiana.pp.47.

17. Tee HP, How SH, Jamalludin AR, Safhan MNF, Sapian MM, Kuan YC, et al. 2009. Risk Factors Associated with Development of Dengue Haemorrhagic Fever or Dengue Shock Syndrome in Adults in Hospital Tengku Ampuan Afzan Kuantan. Med J Malaysia.pp.64.

18. Moraes GH, Duarte EdF, Duarte EC.2013.Determinants of Mortality from Severe Dengue in Brazil: A Population-Based Case-Control Study. AmJ Trop Med Hyg.88.pp.670-676.

19. Miko T, Kusminarti S, Karyanti MR, Sugiharti S, Sihombing B, Riyanti F, et al. 2011. Modul Pengendalian Demam Berdarah Dengue. Jakarta: Kementerian Kesehatan Republik Indonesia Direktorat Jenderal Pengendalian Penyakit dan Penyehatan Lingkungan.

20. Hakim L, Ruliansyah A. 2015. Hubungan Keberadaan Larva Aedes spp dengan kasus Demam Berdarah Dengue di Kota Bandung. ASPIRATOR.;7.pp.74-82.

21. Pradipta Y.2016.Determinan Sosial Kejadian Dengue Shock Syndrome (DSS) di Kota Semarang Provinsi 
Jawa Tengah. Jogjakarta: Universitas Gajah Mada.

22. Arauz MJ, Ridde V, Hernandez LM, Charris Y, Carabali M, Villar LA. 2014.Developing A Social Autopsy Tool for Dengue Mortality: A Pilot Study. PloS one.pp.10.

23. Harisnal. 2012. Faktor-faktor Risiko Kejadian Dengue Shock Syndrome pada Pasien Demam Berdarah Dengue di RSUD Ulin dan RSUD Ansari Saleh Kota Banjarmasin Tahun 20102012. Depok: Universitas Indonesia.

24. Potter PA, Perry AG. 2005. Fundamentals of Nursing (6th ed). St Louis: Mosby Elsevier.

25. Maryani L, Muliani R. 2010. Epidemiologi Kesehatan Pendekatan Penelitian. Jogjakarta: Graha Ilmu.

26. Guzman MG, Kouri G, Bravo J, Valdes L, Vasquez S, Halstead SB. 2002. Effect of Age on Outcome Of Secondary Dengue 2 Infections. International Journal Infectious Dissease;6:118-24.

27. Thai KT, Nishiura H, Hoang PL, Tran NT, Phan GT, Le HQ, et al. 2011. Agespecificity of Clinical Dengue During Primary and Secondary Infections. Plos Neglected Tropical Diseases; 5: 1180.

28. Fulara SN, Fulara NY. 2017. Dengue Shock Syndrome: An Experience from a Tertiary Level Hospital in Mumbai. International Journal of Contemporary Medical Research;4:173-5.

29. WHO. 2005. Dengue, Dengue Haemorrhagic Fever and Dengue Shock Syndrome in the Context of the Integrated Management of Childhood Illness: WHO Departement of Child and Adolescent Health and

30. Development.

Khurram M, Qayyum W, Hassan SJ, Mumtaz S, Bushra HT, Umar M. 2014. Dengue Hemorrhagic Fever: Comparison of Patients with Primary and Secondary Infections. Journal of
Infection and Public Health;7.pp.489495.

31. Samanta J, Sharma V. 2015. Dengue and Its Effects on Liver. World Journal of Clinical Cases.;3.pp.125-131.

32. Ahmed F. Dengue and The Liver.2017. SM Journal of Hepatitis Research and Treatment; 1.pp.1002.

33. Deepak A, Patel ND.2006. Differentia Diagnosis of Acute Liver Failure in India. Annals of Hepatology;5.pp.150 156.

34. Jagadishkumar K, Jain P, Manjunath VG. 2012. Hepatic Involvement in Dengue Fever in Children. Iran Journal Pediatric;22.pp.231-236.

35. Zhang $\mathrm{H}$, Zhou YP, Peng HJ, Zhang XH, Zhou FY, Liu ZH, et al. 2014. Predictive Symptoms and Signs of Severe Dengue Disease for Patients with Dengue Fever:A Meta-Analysis. BiomedResearch International. pp.110.

36. Seneviratne SL, Malavige GN, de Silva HJ. 2006. Pathogenesis of liver involvement during dengue viral infections. Transactions of the Royal Society of Tropical Medicine and Hygiene; 100.pp.608-614.

37. Pongpan S, Wisitwong A, Tawichasri C, Patumanond J. 2013. Prognostic Indicators for Dengue Infection Severity. International Journal Clinic and Pediatric; 2.pp.12-18.

38. Ledika MA, Setiabudi D, Dhamayanti M. 2015 Association between Clinical Profiles and Severe Dengue Infection in Children in Developing Country. AMerican Journal of Epidemiology and Infectious Disease; 3.pp.45-49.

39. Putra Y, Arhana BNP, Safitri I, Widiana R. 2014. Serum Transaminase Levels and Dengue Shock Syndrome in Children. Paediatrica Indonesiana; 54.pp.181-185.

40. Souza LJ, Pessanha LB, Mansur LC, 
41. Laboratory Characteristics Between Children And Adults with Dengue. The Brazilian Journal of Infectious

42. Suwarto S, Ulhaq S, Widjaja B.2017.Combination Of Three Laboratory Data As Predictor of Severe Dengue In Adults : A Retrospective Cohort Study. Universa Medicina; 36.pp.19.

43. Mayetti. 2011. Hubungan Gambaran Klinis dan Laboratorium sebagai
Diseases : An Official Publication of The Brazilian Society of Infectious Diseases. 2013; 17.pp.27-31.

Faktor Risiko Syok pada Demam Berdarah Dengue. Sari Pediatri; 11.pp.367-373.

44. Pongpan S, Wisitwong A, Tawichasri C, Patumanond J, Namwongprom S. 2013. Development of Dengue Infection Severity Score. ISRN Pediatrics.pp.1-6. 